\title{
Examining Constitutional Changes in Bosnia and Herzegovina: Hampering the Europeanization Process?
}

\section{Bedrudin Brljavac}

\author{
University of Sarajevo, Bosnia and Herzegovina
}

\section{Introduction and Research Question}

Serious divisions and weaknesses regarding its policies and activities at international level had made the European Union states passive and paralysed when the conflicts in former Yugoslavia started one after another. That is, it is even hard to say that EU member states had a common position and view on the Bosnian war in 1992-95 since they looked paralysed and ineffective and did not develop any constructive and visible policy instruments towards the Bosnian crisis although new political developments at the Balkan region took place at their doorsteps. Thus, in the aftermath of international independence of Bosnia and Herzegovina (hereinafter, only Bosnia or BiH) the EU left the country at mercy of fierce nationalist struggles and neighboring states' ambitions to divide the country (Hadžikadunic, 2005: 27). While many expected this conflict to be an opportunity for the EU to prove its diplomatic and political strength in conflicting regions the result was just an opposite. As Javier Solana claimed, "when the Yugoslav wars broke out in the 1990s we watched as our neighbourhood burned because we had no means of responding to the crisis" (2009). In fact, the Yugoslavian conflict clearly demonstrated global balance of power, that is, proving European lack of commitment and military instruments and displaying the US as a key mediation actor which made critical efforts to end the war in November 1995 when the warring sides signed the Dayton Peace Agreement (DPA). In the beginning of the Yugoslav wars, the Luxembourg Foreign Minister Jacques Poos, then head of the EC Presidency, declared that the organization would intervene in the Yugoslav crisis because it was "the hour of Europe, not the hour of the United States" (Gordon 1997/1998, 75). However, this did not happen and the Bosnian war was 
the hour of the US. The passive stance of the EU showed rather clearly that the Europeans lacked cohesiveness, determination and the instruments to bring the crisis under control (Lehne, 2004: 11). Thus, peace to Bosnian lands was brought mainly by intensive mediation and diplomatic efforts by the US officials designing the DPA as a country's future legal framework.

In other words, the war in BiH ended in December 1995 when the Dayton Peace Agreement was signed. Thus, BiH's current political system is the product of the DPA (Bieber, 2006: 40). The signed Agreement established the Constitution of $\mathrm{BiH}$ supposes division of the country into two Entities: the Bosniak/Croat Federation of $\mathrm{BiH}$ (controlled by the Bosniaks and Croats), and the Republika Srpska (governed by the Serbs). Both Entities have their own political and administrative structures. The Federation of $\mathrm{BiH}$ is divided into three levels: the Entity level, the Cantonal level, and the Municipal level. The RS does not have a cantonal level, it only has municipalities. Overall, the DPA kept Bosnia as independent and sovereign country with a joint multi ethnic government. The DPA has produced an institutional framework where the entities have powers which hinder effective decision-making processes and thus largely leads to rise in ethnic polarization (Lexau, 2004: 7). Also, one of the most important goals of the DPA, restoration of security and physical infrastructure, has been satisfactorily met. However, the broader objective of organizing a multi-ethnic, democratic, and economically self-sustaining country is still a long way to happen (Daalder and Froman, 1999: 107). That is, while the DPA brought the war to an end and laid the foundation for consolidating peace, many observers also believe that the agreement as a document reflects wartime circumstances cannot by itself ensure BiH's future as a functioning democratic state (Ashdown, 2005).

In other words, Bosnia and Herzegovina has been facing almost two decades long political and administrative paralysis due to slow and insufficient progress on necessary constitutional reforms expected from domestic political elites. In fact, Bosnian political representatives are expected to implement necessary changes in the country's constitutional framework to make it more democratic, functional and inclusive, as an important part of its Europeanising reform process that the country has been passing through since the end of the war in 1995. What's more, successful Europeanization process in Bosnia can not continue without much expected constitutional reforms. In other words, all existing "incompatibilities between Bosnia and Herzegovina's constitutional framework and the ECHR need to be addressed in order to ensure improved elections in 2010 elections and full compliance with the SAA requirements" (EC, 2009: 15). Further, Lippman points out that the local leaders in Bosnia are aware that, if their bid for accession to the $\mathrm{EU}$ is to be taken seriously, they will have to reform the state constitution (2006). 
However, since local ethnic politicians hold opposing views over the question of constitutional reform it has proved rather difficult to reach a compromise on the necessary changes in the country's constitutional framework. Similarly, unclear and vague position of the EU member states on necessary and sufficient modifications on the Bosnian constitution is further deepening political deadlock in BiH. As Govedarica claims: "It is true that the EU has had no clear stance towards Bosnia. For a long time the EU officials have believed that the mere process of European integration will solve the country's problems. However, when it was clear that it was not the case then the EU could not find adequate alternative instrument" (2010). Thus, here our main question is:

To what extent has the EU been responsible for insufficient changes with regard to the constitutional framework in Bosnia and Herzegovina?

\section{Theoretical Perspective and The European Standards}

Both in terms of administrative and democratic governance the Bosnian constitution is in tremendous need of some sort of change and reform. Better to say, the country can not move forward on its road to the European union membership under current constitutional framework. Therefore, the Bosnian government has to implement European democratic and effective administration standards that are based both on the Copenhagen and Madrid criteria, respectively. In other words, both Copenhagen and Madrid criteria set the standards and rules that define whether an applicant country is eligible to enter the EU. Laid down at the June 1993 European Council in Copenhagen, the Copenhagen criteria states that, among other things, candidate country has to achieve stability of institutions guaranteeing democracy, the rule of law, human rights, and respect for and protection of minorities. Also, the Madrid criteria agreed in 1995 require that the applicant country must adjust its administrative structures to successfully implement EU reforms. Thus, these are the criteria that a country must fulfil to become the full EU member. Furthermore, any European state that respects the EU values and democratic principles may apply to become the EU member. It is this understanding of democratic transition that constitutes the logic of the Copenhagen political criteria. Therefore, to ask an applicant country to meet the Copenhagen political criteria in order to start the full accession negotiations means the realization and implementation of democratization reforms in that country (Keyman and Duzgit, 2006: 3). For instance, the EU has vigorously stimulated and pushed the democratization reforms by pressing the CEE countries into carrying 
out necessary human rights reforms and implementing open political system (e.g. Linz and Stepan, 1996; Kopecky and Mudde, 2000).

That is, each country that aspires to become the EU member has to make some changes in its political, legal, and economic policies and thus shaping its future increasingly with common values, interests, and norms which are agreed in Brussels. Haas defined this process as a 'process whereby political actors in several distinct national settings are persuaded to shift their loyalties, expectations and political activities toward a new centre, whose institutions possess or demand jurisdiction over the pre-existing national states' (Haas, 1958, 16). Thus, the process of integration of the aspirant country into Brussels political and economic structures is conditioned upon implementing necessary standards and measures that are set beforehand by the EU officials through both Copenhagen and Madrid criteria. Thus, as other candidate and potential candidate countries, Bosnia is also expected to carry out necessary set of reforms which are built in these two criteria. In fact, this process is better known as Europeanization process which has become significant part of the Bosnian political reality. That is, since the mid-nineties the domestic 'shift' was inbuilt in the administrative oriented analysis of domestic patterns of adaptation to EU membership (Boerzel, 1999; Zeff and Pirro, 2001). As defined by Radaelli, Europeanization means a set of "processes of (a) construction (b) diffusion and (c) institutionalization of formal and informal rules, procedures, policy paradigms, styles, 'ways of doing things' and shared beliefs and norms which are first defined and consolidated in the making of EU decisions and then incorporated in the logic of domestic discourse, identities, political structures and public policies" (Radaelli, 2003, 30). Finally, Vink and Graziano provided a broad definition of Europeanization as a process of "domestic adaptation to European regional integration" (Vink and Graziano, 2007: 7). Also, Europeanization signifies a means and an end; it represents method as well as substance; it defines a project and a vision (Anastasakis, 2005). Thus, it is the European Union as attraction force that should clearly stress what are the necessary reforms and standards that must be implemented by the Bosnian government if they want their EU aspirations stay alive.

\section{Weaknesses and Shortcoming of the Dayton Agreement}

So far, the Dayton Agreement proved to have serious democratic weaknesses and thus blocking political and economic progress of the country. In other words, in terms of both democratic inclusiveness and administrative effectiveness the Bosnian constitutional framework based on the DPA has proved rather deficient. In 
fact, the citizens from minority groups such as the Roma, Turks, or Jews, are granted only a limited degree of self-administration (Soberg, 2008: 715). For instance, according to current Bosnian constitutional framework candidacy of "others" or members of the minority groups is blocked to the posts of State Presidency and the House of Peoples. These positions are designed to be filled up by the three largest ethnic groups, the so-called 'constituent' peoples, i.e. Bosniaks, Serbs, and Croats. However, on December 2009 the European Court of Human Rights in Strasbourg over the famous Finci-Sejdic case decided that preventing the members of minority groups from country's political posts is a clear discriminating act. Thus, the entire constitution enshrines ethnic discrimination as a principle of law; because of this discrimination, the Dayton-created constitution could theoretically prevent $\mathrm{BiH}$ from joining either the Council of Europe or the EU (Lyon: 2000: 112). Furthermore, regarding an administrative framework built in the DPA the country has very cumbersome, economically unsustainable, and fragmented bureaucracy. For example, a total number of ministers all over the country including state and entity levels adds up to 155 . Thus, such a bureaucracy produces unnecessary duplication and an obvious loss of money. Overall, the Bosnian political system is built on a complex, decentralized, multi-layered and mainly ethno-political power-sharing model (Muehlmann, 2009, 141).

However, even it has become clear to all that the current constitution is seriously discriminating against minority groups in the country even two years from the court's ruling have passed the country's politicians have not yet removed discriminatory provisions from the constitution due to their radically different ethnic interests over the issue. That is why, some scholars view Bosnia as a kind of ethnic-nationalist country rather than genuine democratic country or consolidated democracy. As Asim Mujkic points out: "I call a community characterized by the political priority of the ethnic group(s) over the individual that is implemented through democratic self-legislation, and a community characterized by the political priority of the ethnic group's right to self-determination over the citizen's right to self-determination where the citizen's membership in a political community is determined by her or his membership in ethnic community, Ethnopolis. And I call the political narrative and practice intended to justify this ethnically-based social construct, ethnopolitics" (2007: 116). Thus, Bosnia is still a profoundly undemocratic country even though it is seriously entrenched on the European integration process. What's more, discriminatory constitution is blocking country's further moves towards the European Union membership. When we come to expected reforms regarding the administrative framework very little progress has been made in terms of making the state government stronger and more functional. That is, the European Union has sought for strong and united state government with whom to conduct more effective negotiations and establish better bilateral 
relations. Despite rise in central state competences it is still weak and dysfunctional. Thus, Dayton Agreement has failed to resolve the basic political and social cleavages around which warring parties were in the three-year conflict thus only changing the means by which ethnic groups are still fighting for their separate statehood (Woodward, 1997: 29). As a result, current state administration is still unable even to successfully implement acquis communautaire. What is more, the International Crisis Group concluded that $\mathrm{BiH}$ still is not a competent state, let alone one that inspires or enjoys the loyalty of all its citizens (ICG, 2002: 15).

\section{'The Europe Union Divided'}

Turkes points out that "the EU is not committing itself enough to create necessary platform to integrate $\mathrm{BiH}$ into the EU structures. Given the fact that current EU vision from Thessalonica to today has been to keep $\mathrm{BiH}$ at arms length, the EU has followed a strategy of 'neither total exclusion nor a rapid integration" (2010). Thus, in terms of the necessary constitutional changes so far the EU has not been quite clear and has not defined concrete standards that should be adopted by the Bosnian government which would make its constitution more democratic and more functional. Although the EU politicians have very often stated that Bosnia cannot realize its EU membership aspirations if it does not make some sort of modifications on its constitution most of them have not clearly stressed what are the constitutional changes required and expected from the Bosnian side. Therefore, Bassuener and Lyon claim that "Most of all, the EU needs to articulate clearly to both politicians and citizens what level of functionality $\mathrm{BiH}$ needs to have attained before becoming a viable candidate for membership in the EU, ... The EU must put forth a set of guidelines on what sort of $\mathrm{BiH}$ it can accept into its ranks, with clarity on what elements are unacceptable" (2009: 13). As a result, since the Bosnian Europeanization process the EU has held unclear and vague position on necessary and sufficient changes on the Bosnian constitution. Furthermore, for such an ambiguous position of the EU politicians we can to some extent accuse flexibility and openness to political manipulation of both the Copenhagen and Madrid criteria. In other words, the Copenhagen and Madrid criteria can be comprehended in hundred of different ways by different actors. Thus, the political conditions have been ambiguously defined and therefore caused disorientation within targeted governments regarding the necessary steps to take that would have satisfied the EU officials (Mineshima, 2002). Thus, the EU has not utilised the potential and capacity that the Copenhagen and Madrid criteria can provide, thus playing only marginal and weak role in the Europeanisation process in Bosnia and Herzegovina. 
It seems that the similar thing happened to the member states since they have very diverse views on sensitive political issues such as the shape of the future constitutional reforms in Bosnia. For instance, the former US Ambassador Charles English argued that "part of the problem is that the EU itself is divided about Bosnia. Among member states, only a handful, most notably the UK, appear to have a clear grasp of the dangers posed by Bosnia's current political dynamics" (Tanner, 2011). Better to say, the member states do not have common position and they do not "speak with single voice" with regards to necessary changes in the Bosnian constitution. Thus, the European Commission President Barroso pointed out that while constitutional reform was not a strict condition for signing the SAA, "there is [a] link between these two processes ... The EC and EU have to be convinced that they have a partner in $\mathrm{BiH}$, which will be capable to respect its promises and implement the Agreement that we negotiate now" (2006). Also, Welner Almhofer, Austrian Ambassador to $\mathrm{BiH}$, claims that the EU had never set the successful implementation of constitutional reforms as a condition for BiH's EU membership (2006). Furthermore, Solana pointed out in his speech "I do not think it would be a good idea to open Dayton again at this moment. Of course, if there is an agreement between the three sides on some arrangements or solutions, I would not be against it . . . [but] I very much hope that as time goes by you will have the discipline and the energy to do this alone, without the need for pressure and impulse from the international community" (2004). Thus, the EU has demonstrated its weaknesses and that it does not have clear-cut answer towards the Bosnian deadlock and European politicians have often thought that mere process of European integration will help the country to solve its political and economic problems. In that regard, Demetropoulou warns that without clear and visible EU commitment the outlook will remain poor for the Western Balkans in general; the vicious circle will remain, as well as the European border north of the Balkan region (2002: 104).

\section{Conclusions and Recommendations}

Without doubt a long-lasting status quo on the constitutional modifications in the post-war Bosnia and Herzegovina has been one of the most triggering political problems that the country has been facing over the previous two decades. Although Bosnian political leaders several times tried to reach an agreement on the constitution they have could not overcome their radical positions. In other words, as domestic politicians have different views and interests on how the future constitution should look like it has proved rather difficult and now almost impossible to reach a compromise on the necessary changes and modifications. 
What is more, the European Union politicians expect the Bosnian political elites to agree on the constitutional changes that will satisfy all the three ethnic communities although they know that it is a very naïve to wait for consensus on such a sensitive political and legal question for even more developed democratic countries. Although it is the Copenhagen and Madrid criteria that should define and clearly set the measures and legal standards that have to be implemented into the domestic policies by the Bosnian politicians, the EU member states have not demonstrated a common and clear position on required constitutional changes in Bosnian and Herzegovina. Thus, it seems that the EU member states are as divided as the Bosnian political elites are over the design and structure of the Bosnian constitution. In addition, from the very beginning of the Bosnian Europeanisation process the EU leaders and its officials have believed that the mere process of a European integration will solve the country's political, economic, and legal problems. However, the EU leaders should not forget that Europeanisation process is 'a two-way street' process in which Brussels puts the pressure on obstructing political forces in the EU aspirant country. Most importantly, if the EU aspires to become powerful and influential actor in international politics then it firstly has to demonstrate its power and transforming capabilities in its closest backyard.

\section{References and Notes:}

1. Almhofer, Welner, (2006), Austrian Ambassador to BiH, Welner Almhofer, cited in OHR, BiH Media Round-up, 26 January 2006.

2. Anastasakis, O. (2005) The Europeanization of the Balkans, The Brown Journal of World Affairs, vol. XII, no. 1.

3. Ashdown, Paddy, (2005), "A superb agreement to end a war, but a very bad agreement to make a state", Former HR in BiH, Lord Paddy Ashdown, Farewell, Sarajevo, The Guardian, 2 November 2005, www.guardian.co.uk/article/o..i6o64.8Q.oo.html.

4. Barroso, Jose Manuel, (2006), cited in OHR, BiH Media Round-up, 18 February 2006.

5. Bassuener, Kurt, and Lyon, James, (2009), "Unfinished Business in Bosnia and Herzegovina: What Is To Be Done?”, United States Institute of Peace, Washington, www.usip.org.

6. Bieber, Florian, (2006). Post-war Bosnia: ethnicity, inequality, and public sector governance, Palgrave Macmillan.

7. Boerzel, T. (1999), 'Towards Convergence in Europe? Institutional Adaptation to Europeanization in Germany and Spain', Journal of Common Market Studies, 37/ 4, 573-596.

8. Daalder, Ivo H, and Froman, Michael B.G. (1999). "Dayton's Incomplete Peace”, in: Foreign Affairs. November/December 1999. pp. 106-113. 
9. Demetropoulou, Leeda, (2002), "Europe and the Balkans: Membership Aspiration, EU Involvement and Europeanization Capacity in South Eastern Europe", in Southeast European Politics, Vol. III, No. 2-3, pp. 87-106.

10. EC, European Commission, (2009). "Commission Staff Working Document, Bosnia and Herzegovina 2009 Progress Report accompanying the Communicatiion from the Commission to the European Parliament and the Council, Enlargement Strategy and Main Challenges 2009-2010", Brussels, 14.10.2009.

11. Gordon, Phillip H., (1997/1998). "Europe's Uncommon Foreign Policy”, International Security, Vol.22, No. 3, pp. 74-100.

12. Govedarica, Dobrila, (2010). "The Executive Director at Open Society Fund-Bosnia and Herzegovina”, Personal Interview, May, 2010.

13. Graziano, P. and Vink, M.P. (eds) (2007), Europeanization: New Research Agendas, Basingstoke: Palgrave Macmillan.

14. Hadžikadunic, Emir, (2005), Od Dejtona do Brisela, ACIPS, Sarajevo.

15. Haas, E. B. (1958) The Uniting of Europe: Political, Social and Economic Forces, 1950-1957, Stanford, CA: Stanford University Press.

16. ICG, International Crisis Group, (2002). "Bosnia's Alliance for (Smallish) Change", Balkan Report No. 132, 2 August 2002, available at www.crisisweb.org/projects/balkans/bosnia.

17. Keyman, Fuat. E., and Duzgit Senem A., (2006), "Europeanization, Democratization and Human Rights in Turkey", in the Center for Economics and Foreign Policy Studies, http://jmp.iku.edu.tr/Keyman6.pdf.

18. Kopecký, Petr and Mudde, Cas (2000) 'What has Eastern Europe taught us about the democratization literature (and vice versa)?', European Journal of Political Research 37, 517-539.

19. Lehne, Stefan, (2004). "Has the 'Hour of Europe' come at last? The EU strategy for the Balkans”, in J. Batt (ed.), The Western Balkans: Moving On, Chaillot Paper No. 70, Institute for Security Studies, Paris, 2004, p. 11.

20. Lexau, Skjold-Siw, (2004), "Bosnia and Herzegovina", Advisor to the Political Department Office of the High Representative, 2003-2004”, NORDEM Report 16/2004.

21. Linz, Juan, J., and Stepan, Alfred, (1996b). “Toward Consolidated Democracies", Journal of Democracy, 7/2: 14-33.

22. Lippman, Peter, (2006), "On 10th Anniversary of Dayton Accord: Are Changes in Bosnia Real or Rhetorical?”, Special Report: Washington Report, January/February 2006, pages 38-39.

23. Lyon, James, M.B., (2000), “Will Bosnia Survive Dayton?”, Current History, March, 2000 .

24. Mineshima, D. (2002) The Rule of Law and EU Expansion, Liverpool Law Review, vol. 24.

25. Muehlmann, Thomas, (2009). Police Restructuring in Bosnia-Herzegovina: Problems of internationally led security sector reform, in Chandler, David, (2009). Statebuilding and Intervention: Policies, Practices and Paradigms, Routledge, New York.

26. Mujkić, A (2007) We, the Citizens of the Ethnopolis, Constellations, Volume 14, Issue $1,112-128$. 
27. Solana, J, (2004), “The European Journey” London, UK: Institute for War and Peace Reporting: Balkan Crisis Report No. 493, April 22, 2004, available at www.iwpr.net. 28. Radaelli, Claudio, M. (2003). The Europeanization of Public Policy, in Featherstone, Kevin and Radaelli, Claudio, M. (2003). The Politics of Europeanization, Oxford University Press.

29. Soberg, Marius, (2008), "The Quest for Institutional Reform in Bosnia and Herzegovina", East European Politics and Societies, 2008; 22; 714 originally published online Sep 8, 2008.

30. Solana, Javier, (2009), "EU makes its mark on the world stage", Guardian, 11 October 2009, www.guardian.co.uk.

31. Tanner, Adam, (2011), "Bosnian Serb leader threat to stability: U.S. Cables", in Reuters, April 2011.

32. Turkes, Mustafa, (2010), "Professor at the Department of International Relations, Middle East Technical University", Personal Interview, April, 2010.

33. Woodward, Susan, (1997). "Bosnia", The Brookings Review 15:2 (Spring 1997), pp. 2931.

34.Zeff, E.E. and Pirro, E.B. (eds) (2001), The European Union and the Member States: Cooperation, Co-ordination and Compromise, Boulder, CO: Lynne Rienner. 


\title{
Summary
}

\section{Examining Constitutional Changes in Bosnia and Herzegovina: Hampering the Europeanization Process?}

\author{
Bedrudin Brljavac \\ University of Sarajevo, Bosnia and Herzegovina
}

Without doubt a long-lasting status quo regarding the constitutional changes in the post-war Bosnia and Herzegovina has become one of the most triggering and challenging political questions the country has been grappling with for so long. Different political interests and views of the three biggest ethnic communities in Bosnia on the future country's constitutional framework have prevented them to reach a viable agreement. Thus, it has become naïve to expect that domestic political elites on their own will reach an agreement on the constitutional reforms. Nevertheless, the European Union has repeatedly been sending the messages and statements that constitutional changes must be agreed by Bosnian politicians alone. Also, while the EU politicians have often pointed out that Bosnia cannot realize its EU membership aspirations if it does not make some sort of modifications on its constitution, most of them have not clearly stressed what are the concrete constitutional changes which the Bosnian politicians have to implement. As a result, unclear and ambiguous position of the EU member states on necessary and sufficient changes on the Bosnian constitution has further deepened a political deadlock in Bosnia.

Key Words: Bosnia and Herzegovina, Dayton Agreement, European Union, Europeanisation, Copenhagen Criteria 